内田俊一**.小川茂**.平田光穂**

島田源嗣***-下川四郎****

メタノール・水, アセトン・水，アセトン・メタノールの三つの二成分系の沸点対液租成䦥保

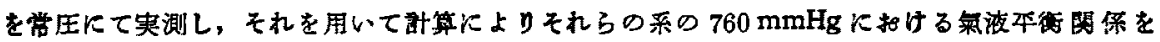
求め, 既往の交缡と此校した。

\section{1. 緒霄}

二成分采の気液平衙関保か蒸留荅の設計记当つて必要 ーとあることは紊知のことであるが，その実測にはかなり の熟練と㭙間とを要することもまた事些でする。そこで 我々は比較的簡単に溶液の沸点を実測できる装置により 二成分系の沸点対液粗成関係を決定し，それを用いて計 算によつてその系の気液平衡関係を求めるといら方法を

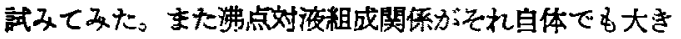
価値をるつていることるあきらかなことであるので， そのデータを供給することも我なの目的の一つである。 我々の用いた进点湘定 䒾置については，別に 報告することになつて いるので本報ては沸点 の夹測データを直にか ப゙ゲることににする。实 測した系はメタノー ル・水, アセトン・水, アセトン・メタフール の三つである。

\section{2. 沸点対液組成} 関保

実験に使用したメタ ノール顿よ゙すセトン は共に 90\%以上のる のを精溜塔で数回精溜 し，沸点放よび犗度の 测定の結果, ほとんど 純粋であることをたし かめ大்ののを使用し
た。それらの值を Table 1 に示す。

沸点の実測ダータは Table 2 の通りである。更にこ れらのデータが後の計算の基礎になるので慎重にいわか る smoothed data 求めた。すなわち，普通の沸点曲 線 Fig. 1 を画くと同時に，Fig. 2 の如き变形施点曲 線も画いた。これは，液組成 $x$ から計算した $x /(1-x)$ 。 $=X$ と，沸点 $t$ から

$$
\begin{aligned}
& b=\frac{t_{0}-t}{t_{0}-t_{1}}, \\
& B=\frac{b}{1-b}
\end{aligned}
$$

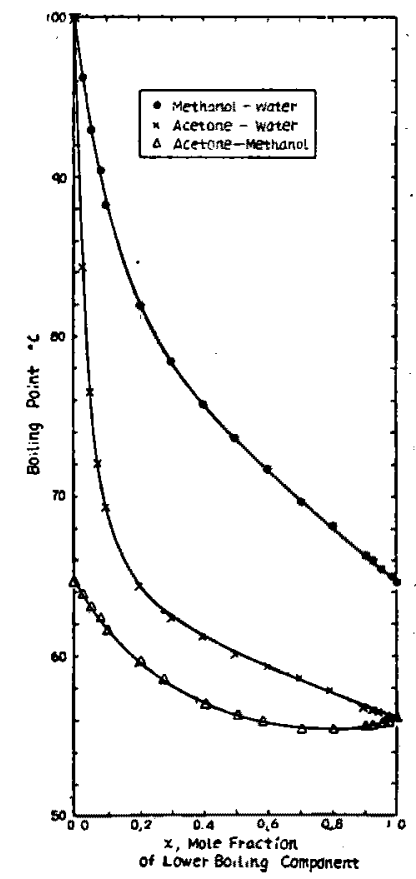

Fig. 1 Boiling point curves for methanol-water, acetone-water and acetone-methanol at $760 \mathrm{mmHz}$

* 昭和 27 年9月 25 日愛理

* 慗工菜大学 *

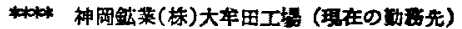




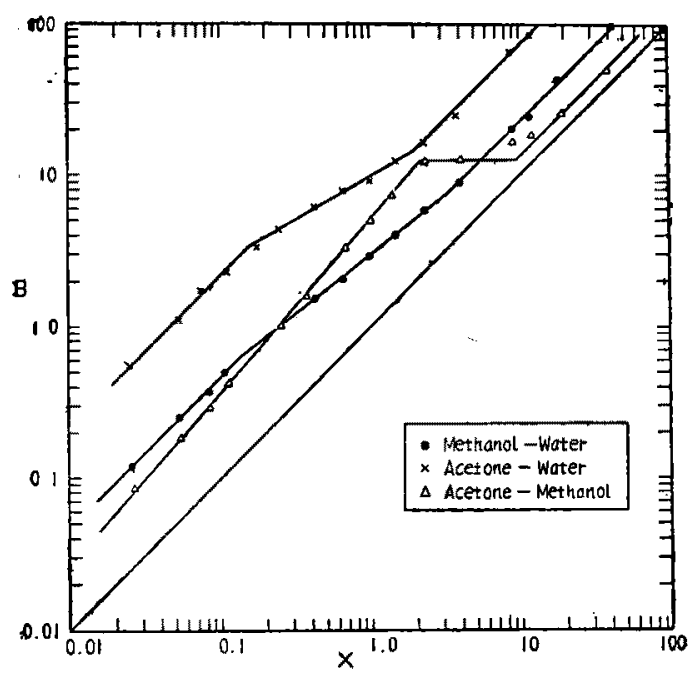

Fig. $2 x-B$ curves for smoothing experimental data

Table 3 Smoothed data of boiling point curves

\begin{tabular}{|c|c|c|c|c|c|}
\hline \multicolumn{2}{|c|}{ Methanol-Water } & \multicolumn{2}{|c|}{ Acetone-Water } & \multicolumn{2}{|c|}{ Acetone-Methanol } \\
\hline$x *$ & B.P. $\cdot{ }^{\circ} \mathrm{C}$ & $x * *$ & B.P., ${ }^{\circ} \mathrm{C}$ & 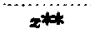 & B.P., ${ }^{\circ} \mathrm{C}$ \\
\hline $\begin{array}{l}0.0 \\
0.05 \\
0.10 \\
0.20 \\
0.30 \\
0.40 \\
0.50 \\
0.60 \\
0.70 \\
0.80 \\
0.90 \\
0.95 \\
1.0\end{array}$ & $\begin{array}{r}100 \\
92.84 \\
88.10 \\
82.12 \\
78.28 \\
75.57 \\
73.45 \\
71.52 \\
69.70 \\
67.97 \\
66.27 \\
65.40 \\
64.59\end{array}$ & $\begin{array}{l}0.0 \\
0.05 \\
0.10 \\
0.20 \\
0.30 \\
0.40 \\
0.50 \\
0.60 \\
0.70 \\
0.80 \\
0.90 \\
0.95 \\
1.0\end{array}$ & $\begin{array}{l}100 \\
77.00 \\
69.10 \\
64.30 \\
62.39 \\
61.19 \\
60.18 \\
59.25 \\
58.38 \\
57.55 \\
56.80 \\
56.47 \\
56.13\end{array}$ & $\begin{array}{l}0.0 \\
0.05 \\
0.10 \\
0.20 \\
0.30 \\
0.40 \\
0.50 \\
0.60 \\
0.70 \\
0.80 \\
0.90 \\
0.95 \\
1.0\end{array}$ & $\begin{array}{l}64.59 \\
63.05 \\
61.73 \\
59.57 \\
58.07 \\
57.04 \\
56.30 \\
55.78 \\
55.50 \\
55.40 \\
55.54 \\
55.75 \\
56.13\end{array}$ \\
\hline
\end{tabular}

* mole fraction of methanol

** mole fraction of acetone

なる式により求めた $B$ とを対数方眼紙に点綴したるの てあり，大体において三つの直線部分上りなつている。 こっで $t_{0}$ は $x=0$ における沸点, すなわち高沸点成分 の沸点， $t_{1}$ は $x=1$ における沸点，十なわち低沸点成分 の沸点である。たら゙アセトン・メタノール系のよ5な共 沸湦合物をつくる系では， $t_{n}$ を共沸温度として共沸点 まで

$$
b=\frac{t_{0}-t}{t_{0}-t_{m}+t_{1}-t_{m}}
$$

共沸点以後は

$$
b=\frac{t_{0}-t_{m}+t-t_{m}}{t_{0}-t_{m}+t_{1}-t_{m}}
$$

なる式により計算した。

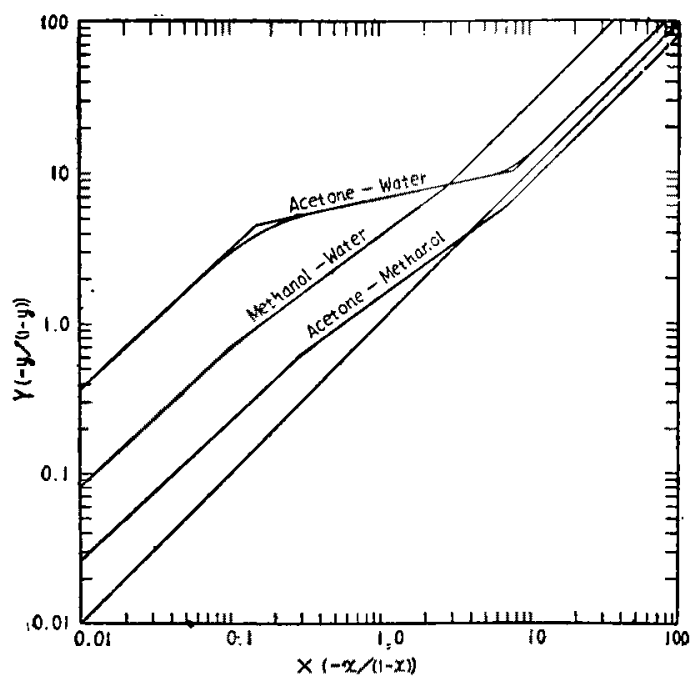

Fig. 3 Calculated $X-Y$ curves

Table 4 Calculated data for $X-Y$ curves $\left(Y=\alpha X^{n}\right)$

\begin{tabular}{cccc}
$\begin{array}{c}\text { Coordinate of } \\
\text { straight portion }\end{array}$ & $\begin{array}{c}\text { Slope of } \\
\text { middle } \\
\text { straight } \\
\text { portion }\end{array}$ \\
\hdashline lower & upper & middle \\
$a_{0}$ & $a_{1}$ & $\alpha$ & $n$ \\
$\mathbf{5 . 8 2}$ & 2.81 & 3.66 & 0.74 \\
26.1 & 1.31 & 6.51 & 0.21 \\
1.87 & 0.83 & 1.48 & $\mathbf{0 . 7 2}$
\end{tabular}

Table 5 Calculated vapor-liquid equi-

\begin{tabular}{|c|c|c|c|c|c|}
\hline \multicolumn{2}{|c|}{$\begin{array}{l}\text { Methanol-Water } \\
\text { mole fraction } \\
\text { Methanol }\end{array}$} & \multicolumn{2}{|c|}{$\begin{array}{c}\text { Acetone-Water } \\
\text { mole fraction } \\
\text { Acetone }\end{array}$} & \multicolumn{2}{|c|}{$\begin{array}{l}\text { Acetone-Methanol } \\
\text { mole fraction } \\
\text { Acetone }\end{array}$} \\
\hline$\underset{x}{\text { liquid }}$ & Vapor & $\underset{x}{l i q u i d}$ & vapor & ${ }_{x}$ & $\begin{array}{c}\text { vapor } \\
y\end{array}$ \\
\hline $\begin{array}{l}0.05 \\
0.1 \\
0.2 \\
0.3 \\
0.4 \\
0.5 \\
0.6 \\
0.7 \\
0.8 \\
0.9 \\
0.95\end{array}$ & $\begin{array}{l}0.269 \\
0.422 \\
0.581 \\
0.662 \\
0.733 \\
0.787 \\
0.831 \\
0.876 \\
0.920 \\
0.962 \\
0.982\end{array}$ & $\begin{array}{l}0.05 \\
0.1 \\
0.2 \\
0.3 \\
0.4 \\
0.5 \\
0.6 \\
0.7 \\
0.8 \\
0.9 \\
0.95\end{array}$ & $\begin{array}{l}0.639 \\
0.763 \\
0.827 \\
0.845 \\
0.857 \\
0.867 \\
0.877 \\
0.897 \\
0.898 \\
0.927 \\
0.962\end{array}$ & $\begin{array}{l}0.05 \\
0.1 \\
0.2 \\
0.3 \\
0.4 \\
0.5 \\
0.6 \\
0.7 \\
0.8 \\
0.9 \\
0.95\end{array}$ & $\begin{array}{l}0.107 \\
0.193 \\
0.335 \\
0.438 \\
0.524 \\
0.597 \\
0.664 \\
0.733 \\
0.800 \\
0.882 \\
0.942\end{array}$ \\
\hline
\end{tabular}
librium data at $760 \dot{\mathrm{mmHg}}$

このよ5にして本めた smoothed data を Table. 3 に示す。

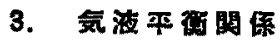

沸点刘液粗成関係から気液平衙開係を求めるには， $X-Y$ 曲線を利用する簡便泆 ${ }^{2}$ を用いた。逐次計算法 


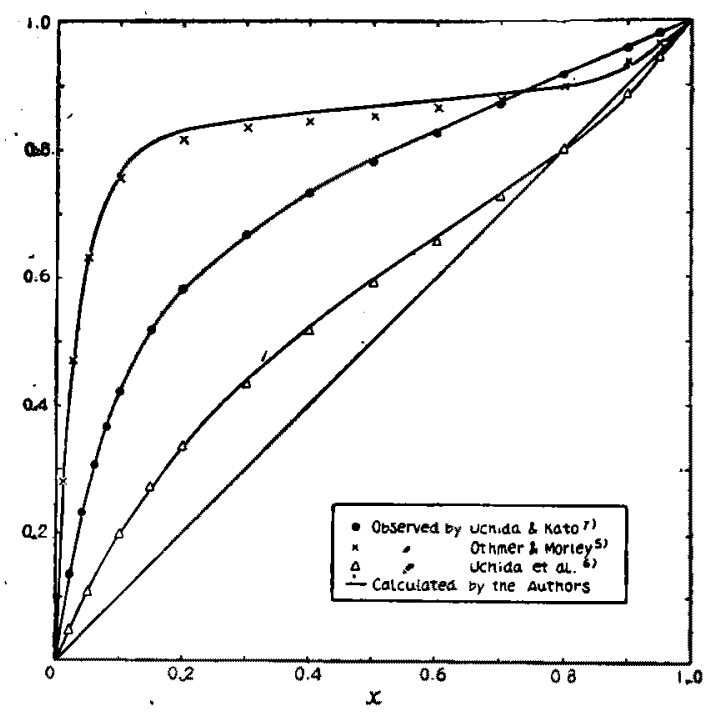

Fig. - Calculated vapor-liquid equilibrium relations at 760 mmHg (Solid lines) compared with the literature

もしてみたが，蒸気組成が中央て幾分高めにでて，計算 か面倒なことと共に前者より分つている。また $X-Y$ 曲 線の中央部分の倾斜をだすに忙 trial and error 法を用

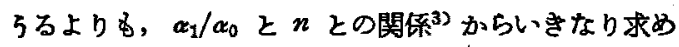
た方が精庭がよい。結局もつとも簡単な方法ががもつと るよい結果を与えることは與味深いことである。な括， 計算に用いる $k$ としては $-(C \log T / T)(d T / d x)$ を $=0.1,0.2, \cdots \cdots, 0.9$ の备么に対して求め点釉して得た 曲線を smooth したるのを用いた。 $k$ としては
一 $\left(C^{\prime} / T^{*}\right)(d T / d x)$ を用いた方が合理的であるがば $上$ の形で邡算えしててしまつた上に，結果はいずれです同 じであるのでそのま〉報告して拓く。

計算結果は Table. 4, 5, Fig. 3， 4 に示す通りて ある。

\section{4. 交䙹との比䂭}

Fig. 4 に計算により求めた $x-y$ 曲線と代表的な実

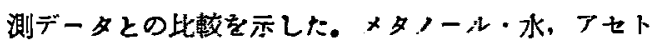
ン・メタフール采では十分て近似度を得ているが，ア セトン・水柔では中失部分で計算値の方が滈目にでて いる。これは計算の途中にあられる式の中に， $X-Y$ 曲線の傾斜がさくなると誤差が大きくなるよらな部 分があるためと思われる。しかしながら，この程度の 差は，直接に平衡関保を実測したデータでる測定者ま たは测定法の相違によつて起り得ることるまた事夹で 怙るから、こ礼の計算結果はすべて，実用上上い近 似を与えたと結論してもよいであろう。

附記：本報交の実的部分は，島田択よび下川が， 卒業研究に扰いて行つたるのが中心をなしている。

\section{女献}

1) 平田：本落，13，138 (1949)

2) 平田：本誌, 14, 16, 65 (1950)

3）平田：本誌，15，72 (1951)

4) 永迥, 平田：本镱，16, 83 (1952)

5) Othmer \& Morley: Tnd.Fng.Chem., 38, 751 (1946)

6) 内田, 小川, 山口： Japan Science Review, Engag, Sec, 1. 41 (1950)

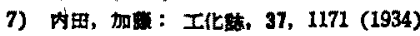

\section{一第2部三成分系の沸点”-}

内田俊一苂. 小们茂**.平田光穂** 竹林 啓***. 星田安正****

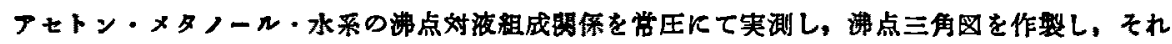
を既往の交献と比校した。

\section{1.}

多成分系の沸点対液租成関系は，多成分柔の蒸溜，抽 出蒸溜, 共进蒸溜などの設計計算に有用なデータの一つ

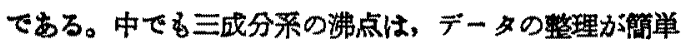

であり，また二成分系との連関も比較的はつきりしてい るので特に有用である。我くはアセトン・メタノール・ 办来につき，二成分采について実測を圪こならと同時に

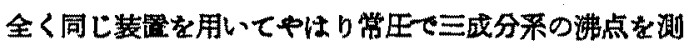

十昭和 27 年9 月 25 日夏理

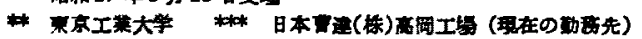

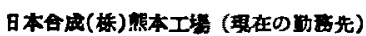

